\title{
Vitrification of Cesium-Loaded Crystalline Silicotitanate (CST) in the Shielded Cells Melter
}

by

M. K. Andrews

Westinghouse Savannah River Company

Savannah River Site

Aiken, South Carolina 29808

T. L. Fellinger

D. M. Ferrara

J. R. Harbour

D. T. Herman

RECORDS ADMINISTRATION

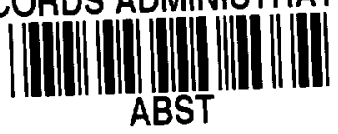

\section{DOE Contract No. DE-AC09-96SR18500}

This paper was prepared in connection with work done under the above contract number with the U. S. Department of Energy. By acceptance of this paper, the publisher and/or recipient acknowledges the U. S. Government's right to retain a nonexclusive, royalty-free license in and to any copyright covering this paper, along with the right to reproduce and to authorize others to reproduce all or part of the copyrighted paper. 


\section{DISCLAIMER}

This report was prepared as an account of work sponsored by an agency of the United States Government. Neither the United States Government nor any agency thereof, nor any of their employees, makes any warranty, express or implied, or assumes any legal liability or responsibility for the accuracy, completeness, or usefulness of any information, apparatus, product, or process disclosed, or represents that its use would not infringe privately owned rights. Reference herein to any specific commercial product, process, or service by trade name, trademark, manufacturer, or otherwise does not necessarily constitute or imply its endorsement, recommendation, or favoring by the United States Government or any agency thereof. The views and opinions of authors expressed herein do not necessarily state or reflect those of the United States Government or any agency thereof.

This report has been reproduced directly from the best available copy.

Available to DOE and DOE contractors from the Office of Scientific and Technical Information, P. O. Box 62, Oak Ridge, TN 37831; prices available from (423) 576-8401.

Available to the public from the National Technical Information Service, U. S. Department of Commerce, 5285 Port Royal Road, Springfield, VA 22161. 
Westinghouse Savannah River Company
Savannah River Technology Center
WSRC-TR-97-00314

September 30, 1997

\title{
VITRIFICATION OF CESIUM-LOADED CRYSTALLINE SILICOTITANATE (CST) IN THE SHIELDED CELLS MELTER (U)
}

\author{
M. K. Andrews, T. L. Fellinger, D. M. Ferrara, J. R. Harbour and D. T. Herman \\ Westinghouse Savannah River Company
}

\section{Introduction and Summary}

Through the Tanks Focus Area, the Savannah River Technology Center (SRTC) and the Oak Ridge National Laboratory (ORNL) participated in a joint project in which supernate waste from the Melton Valley Storage Tanks at Oak Ridge was treated by passage through a crystalline silicotitanate (CST) ion exchange column. ${ }^{1}$ CST was designed to sorb Cs-137, Sr-90 and several other radionuclides from highly alkaline solutions containing large quantities of sodium. ${ }^{2}$ After demonstrating the effectiveness of CST as an ion exchange medium, ORNL shipped some of the loaded sorbent to SRTC where it was mixed with glass formers and processed in a joule-heated melter within the SRTC Shielded Cells.

The remotely operated process included the preparation of the melter feed, vitrification in an $1150^{\circ} \mathrm{C}$ melter and analysis of the glass product both for its composition and its durability. The campaign processed approximately $20 \mathrm{~kg}$ of Cs-loaded CST in 80 hours of operation of the Shielded Cells melter. The glass produced contained between 50 and $55 \mathrm{wt} \%$ loaded CST. This report details the results of the melter run, along with the preparations that were required to complete the campaign.

\section{CST Characterization}

A small sample of loaded CST from ORNL was removed from the top of the drum and dissolved for analysis using a peroxide/hydrofluoric acid/nitric acid dissolution. The resulting samples were analyzed using Inductively Coupled Plasma-Emission Spectroscopy (ICP-ES), Atomic Absorption (AA), and Gamma Spectroscopy. The manufacturer of the CST has requested that the elemental composition not be released, and therefore, only the radionuclide composition is reported in Table 1. It should be noted that ORNL also performed some analyses on the CST and determined that it was neither characteristically hazardous nor TRU (less than $100 \mathrm{nCi} / \mathrm{g}$ alpha). The radionuclide composition that ORNL determined to have loaded on the CST is also included in Table 1. 
Table 1 - Major Radionuclide Composition of Loaded CST (SRTC Analyzed and ORNL Calculated)

\begin{tabular}{|c|c|c|}
\hline Element & SRTC (Ci) & ORNL (Ci) \\
\hline \hline Cs-137 & 19 & 24 \\
\hline Cs-134 & 0.2 & 0.3 \\
\hline Sr-90 & 0.1 & 0.2 \\
\hline
\end{tabular}

The elemental composition of the loaded CST was compared to the unloaded CST composition. The main difference was in the concentrations of sodium and potassium. The loaded CST was pretreated at ORNL with a sodium hydroxide solution to condition the CST and to remove fine particulates and therefore, contained more sodium and potassium. The loaded CST also contained cesium and strontium. The development of the final glass formulation for the melter run addressed these compositional differences.

\section{Glass Formulation Development}

Prior to the vitrification in the SRTC Shielded Cells, a glass formulation had to be developed to incorporate sufficient CST sorbent without significant crystallization. A report detailing the development of a glass formulation using unloaded CST has been written. ${ }^{3}$ Since the composition of the loaded CST was slightly different from the unloaded composition, the original formulation, along with four additional formulations were tested using pretreated (but unloaded) CST, at waste loadings of $50 \mathrm{wt} \%$.

The electrical conductivities for the five formulations were calculated to ensure that they would be compatible with the joule-heated melter. Typically, electrical conductivities between 0.36 and $1.1 \mathrm{Siemans} / \mathrm{cm}$ at $1150^{\circ} \mathrm{C}$ are considered reasonable. Two compositions were at the higher end, but were within the acceptable range, one was above the high end and two were only slightly above the $1.1 \mathrm{Siemans} / \mathrm{cm}$. The calculations were only estimates since the exact contributions of all of the elements present in the glass were not known. Therefore, it was decided to continue testing of all five formulations.

Two samples of each of the five formulations were melted at $1150^{\circ} \mathrm{C}$. The first sample was poured, and the second was subjected to a slower cooling rate, similar to that expected in the Shielded Cells melter. Two of the five samples, including the original formulation, were too fluid when poured. Two of the remaining samples formed crystals when slowly cooled. The fifth composition was within the required viscosity range and did not form crystals upon slow cooling. However, this composition had a calculated electrical conductivity slightly above the acceptable range. Since changing the composition to improve the conductivity could adversely affect the viscosity or the crystallization, it was decided to proceed with this formulation without reducing the waste loading. 
During the development of the glass formulation, a waste loading of $50 \mathrm{wt} \%$ dried CST was used. To ensure that the formulation was robust enough to handle variations in waste loadings, the selected composition was tested at lower and higher waste loadings. Based on the results of these experiments, it was determined that the formulation could easily incorporate CST loadings between 40 and 55 wt $\%$ dry CST. Since the CST received from ORNL contained 8 to $15 \mathrm{wt} \%$ water, the waste loading targeted was equivalent to a final CST loading in the glass between 50 and $55 \mathrm{wt} \%$, depending on the water content of the CST. The appropriate reagent-grade chemicals were then combined to produce the glass-forming chemicals for the melter campaign.

\section{Feed Delivery System}

Once the glass-forming chemicals were combined with the CST, a feed system with the ability to remotely provide feed for the entire melter campaign was required. The feed system needed to accommodate the possibility that several transfers of CST from the drum would be necessary. It was also necessary for the feed system to be able to mix the CST and chemicals to such a degree as to obtain a reasonably homogeneous feed for the melter. The feed was to be delivered to the melter at approximately $25 \mathrm{cc} /$ minute, and the system had to be able to withstand the high radiation fields in the Shielded Cells environment.

Most efforts focused on the delivery of the CST resin as a slurry because SRTC has experience pumping slurries to melters. Early tests with unloaded CST and water indicated that there was essentially no suspension of the solids in the liquid. The extremely low flow at which the feed was to be delivered to the melter did not allow for a velocity high enough to suspend the solids. Agitation in the feed drum was also not sufficient to suspend the solids. A recirculation loop using a diaphragm pump was added. The first system had a smaller line for feeding the melter off of the recirculation loop and used a needle valve for controlling the feed rate. Serious plugging was encountered in the lines and especially in the needle valve.

It was then decided that in order to increase the suspension of the CST solids, the material needed to be ground. The diaphragm pump and the agitator in the feed drum were allowed to grind the material through recirculation. A 90-degree elbow was added to the system to increase the turbulence in the recirculation line. The erosion of this elbow would not be of concern due to the relatively short duration of the demonstration. A private company would have the option of adding an emulsifier to the recirculation line to allow more efficient and consistent grinding of the particles. The implementation of a recirculation loop in conjunction with agitation resulted in the grinding of the CST particles to a small enough size to maintain sufficient suspension and allow the delivery of the material in a reasonably homogeneous slurry. The needle valve in the melter feed line was replaced with a ball valve. A Masterflex pump after the ball valve was used to control the feed rate of the CST material to the melter. A schematic of the slurry feed system is shown in Figure 1. Several connections were added to allow for water flushing of the lines to prevent pluggage. 


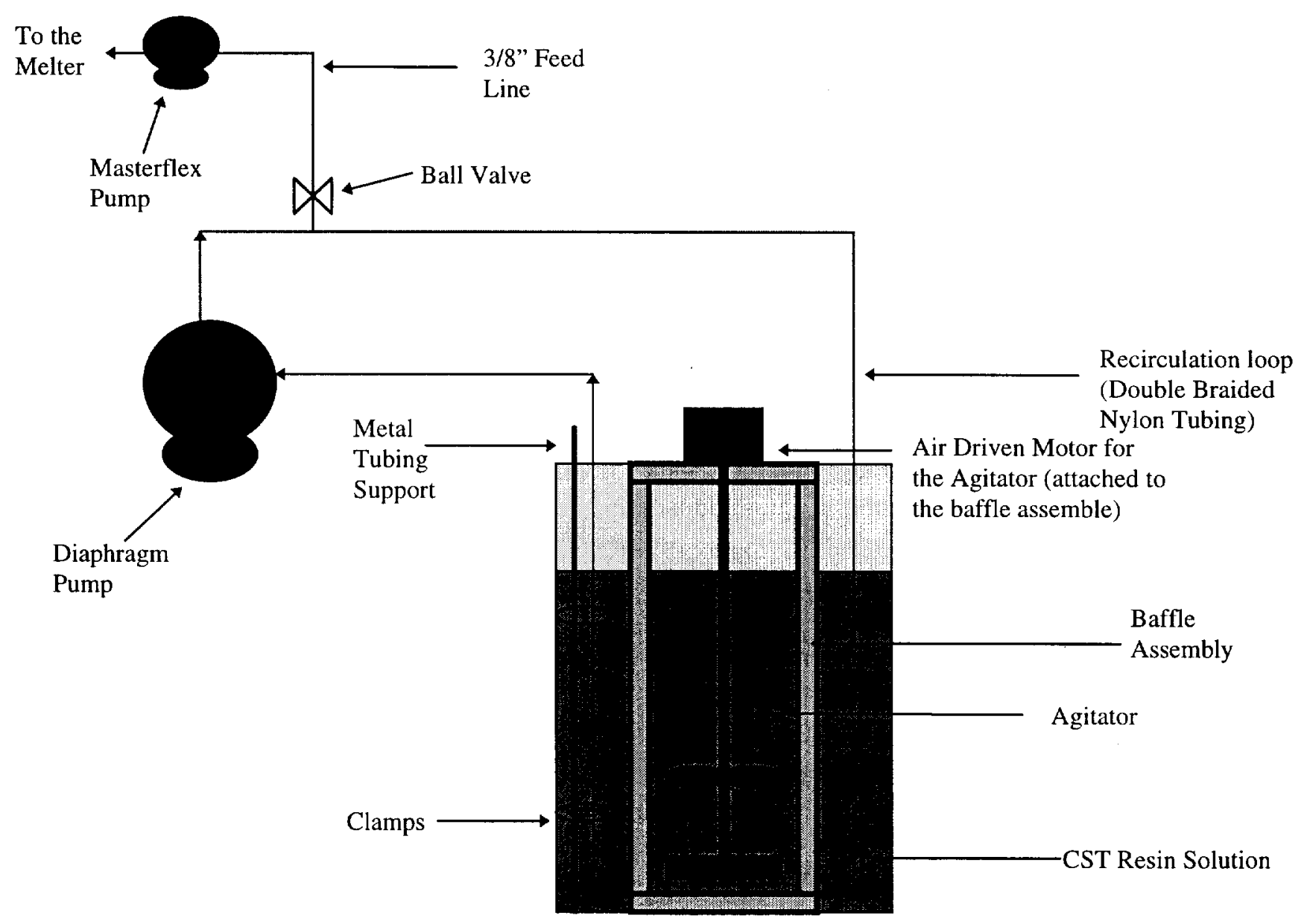

Figure 1 - Schematic of the Melter Feed Tank System in the Shielded Cells

The addition of the glass formers to the CST changed the rheology of the slurry from a thin water-like fluid to a fluid with the consistency of house paint. The particles tended to stay suspended for a longer period of time. Full-scale mock-up testing of the feed indicated that the use of a diaphragm pump and agitator caused sufficient grinding of the material to allow the material to remain suspended. The pumping/mixing setup successfully fed a CST and glass formers solution to the melter at a feed rate of approximately $27 \mathrm{cc} / \mathrm{min}$. Several full pump-down tests were successfully conducted with the CST as well as the CST plus glass former slurries.

Since the slurry feeding system required the addition of water to the CST, additional waste would be created from the condensate generated during vitrification. Therefore, a dry feed system was also tested. A sample of the radioactive CST was combined with the appropriate amount of glass-forming chemicals and was successfully vitrified in a platinum crucible in the Shielded Cells, indicating that dry CST and chemicals could be sufficiently mixed remotely. In addition, nonradioactive frit was added to the Shielded Cells melter as a dry mixture. No problems were encountered during the dry additions. 
Based on the results of this testing, the dry feed system was selected for use during the radioactive melter campaign. However, since both feed systems have been developed and tested, a private vendor would have the option of slurry feeding or dry feeding.

\section{Vitrification Process}

The research melter is a joule-heated melter with two pairs of Inconel $®$ electrodes providing the power to maintain a melt pool temperature of $1150^{\circ} \mathrm{C}$. The cylindrical melt chamber is eight inches in diameter and six inches deep and holds approximately ten kilograms of glass. Two additional heaters are located in the melter above the melt pool to provide supplemental heat which increases the melt rates by vaporizing any water from the feed.

Glass pouring is initiated by tilting the entire melter. The glass flows from the melt pool through a riser cut in the refractory, and out a heated pour spout into 0.5 liter stainless steel beakers. During the CST campaign, the melter ran continuously for 85 hours producing nearly $30 \mathrm{~kg}$ of glass, or the equivalent of three melter turnovers. Prior to the initiation of CST feeding, the melter contained approximately $10 \mathrm{~kg}$ of nonradioactive glass. As feeding of the CST material progressed, the conductivity of the melt pool increased as expected since the CST glass was calculated to be more conductive than the nonradioactive glass. After more than $20 \mathrm{~kg}$ of glass had been produced, the melt temperature was reduced from $1150^{\circ} \mathrm{C}$ to $1125^{\circ} \mathrm{C}$ to lower the current density across the electrodes. With a different melter, this may not have been necessary, but since the Shielded Cells melter has been operating for seven years, it was decided to be conservative. No other melter differences were encountered.

\section{Glass Characterization}

Since the melter contained nonradioactive glass prior to the start of the CST run, samples of glass were taken from the last can poured during the campaign. The last can was chosen because it would have a composition most representative of the feed. Glass from the CST campaign was taken for the purpose of determining its composition and its durability by leaching it according to the Product Consistency Test (PCT) protocol. ${ }^{4}$

The composition of the glass is being measured by dissolving samples of the glass in duplicate and analyzing the resulting solutions by ICP-ES, AA and Gamma Spectroscopy. Appropriate standards are being analyzed along with the CST glass samples to check the accuracy of the analyses.

The PCT is currently being used to determine the durability of the glass. The PCT is a crushed glass leach test that measures the releases of boron, lithium, sodium, and silicon from the glass in $90^{\circ} \mathrm{C}$ ASTM Type 1 water over a period of seven days. The average concentrations are normalized to the chemical composition of the glass. The normalized results for CST glass will be provided in a revision to this report. The HLW acceptance criteria, which states that the glass produced must be more durable than the Environmental Assessment (EA) glass, will be used as the basis for determining acceptability of the CST glass. 


\section{Acknowledgments}

We would like to acknowledge the contributions of Phyllis Workman, Kathy Marshall, Debbie Marsh, Sherry Vissage, Bao Ha, the Shielded Cells Operations, and the Analytical Development Section. This project would not have been successful without their assistance.

\section{References}

1. Joe Walker, LMER Pretreatment, OR1-6-WT-41, (1996).

2. R. Braun et al, "Crystalline Silicotitanate - Novel Commercial Cesium Ion Exchangers", Spectrum '96, Proceedings - International Topical Meeting on Nuclear and Hazardous Waste Management, (1996).

3. M. K. Andrews, "Glass Formulation Development and Testing for the Vitrification of Cesium-Loaded Crystalline Silicotitanate (CST)", 97-MP23.05, Proceedings of the Air \& Waste Management Association's 90 ${ }^{\text {th }}$ Annual Meeting and Exhibition, (1997).

4. ASTM Procedure, C-1286-94, "Determining Chemical Durability of Nuclear Waste Glasses: The Product Consistency Test (PCT)".

5. U. S. Department of Energy, "Environmental Assessment Waste Form Selection for SRP High-Level Waste", USDOE Report DOE-EA-0179, (1982). 


\section{Distribution:}

M. K. Andrews, 773-A

N. E. Bibler, 773-A

D. A. Crowley, 773-43A

J. R. Harbour, 773-43A

D. T. Herman, 773-41 A

E. W. Holtzscheiter, 773-A

T. L. Fellinger, 773-A

D. M. Ferrara, 773-43A

L. F. Landon, 704-1T

K. M. Marshall, 773-43A

L. M. Papouchado, 773-A

C. T. Randall, 704-T

STI, 703-43A 